\title{
Statyba
}

\section{EVALUATION OF SURFACE ROUGHNESS AND VERTICAL SHEAR REINFORCEMENT IN CONTACT ZONE OF REINFORCED CONCRETE CONSTRUCTIONS WITH SURVIVAL MOULDS}

\section{R. Bistrickaitè}

To cite this article: R. Bistrickaite (2000) EVALUATION OF SURFACE ROUGHNESS AND VERTICAL SHEAR REINFORCEMENT IN CONTACT ZONE OF REINFORCED CONCRETE CONSTRUCTIONS WITH SURVIVAL MOULDS, Statyba, 6:5, 322-328, DOI: 10.1080/13921525.2000.10531609

To link to this article: https://doi.org/10.1080/13921525.2000.10531609

Published online: 26 Jul 2012.

Submit your article to this journal $₫$

山 Article views: 78 


\section{GELŽBETONINIŲ KONSTRUKCIJU SU LIKTINIAIS KLOJINIAIS JUNGIAMOJO STRYPYNO IR BETONO PAVIRŠIAUS ŠIURKŠTUMO IVERTINIMAS KONTAKTO ZONOJE}

\section{R. Bistrickaitė}

Kauno technologijos universitetas

\section{Ivadas}

Europos Sajungos valstybèse plačiai taikomos surenkamosios monolitinès perdangų konstrukcijos. Jos yra techniškai racionalios, technologiškos statyti, pakankamai universalios ir ekonomiškos. Lietuvoje šios konstrukcijos dar mažai žinomos.

Nuo mums iprastų ir žinomų surenkamuju ar monolitiniu gelžbetonio plokščiu jos skiriasi tuo, kad perdangos konstrukciją sudaro $4-6 \mathrm{~cm}$ storio gelžbetonio liktinis klojinys - plokšte, ant kurios statybos vietoje liejama kita - monolitinè plokštè. Tokia perdanga armuota tinklais ir erdviniu strypynu ( 1 pav.). Tinklai bei strypyno armatūra apatinèje juostoje perima tempimo jègas, strypyno vertikalusis tinklelis - šlyties jègas surenkamosios plokštès ir monolitinio sluoksnio kontakto plokštumoje (zonoje), o jo viršutinè juosta issitraukia i monolitinio betono gniuždomojo sluoksnio darbą. Sukibimui padidinti plokštès ir monolitinio sluoksnio kontakto zona specialiai sušiurkštinama. Sumontuota ir sukietėjusi perdanga tampa vientiso skerspjūvio konstrukcija ir skaičiuojama kaip ištisinio skerspjūvio lenkiamasis elementas [1]. Tačiau perdangoje esančioje surenkamojo ir monolitinio sluoksnio kontakto zonoje, lenkiant konstrukciją, atsiranda šlyties jègos, kurias naudingai gali perimti jungiamasis strypynas, atlikdamas ne tik montavimo, bet ir konstrukcini vaidmeni. Apibendrintos ir bendros skaičiavimo metodikos, esant ilinkiui, literatūroje nèra. Šiuo darbu siekiama ivertinti skersinio armavimo ir sluoksnių sankibumo įtaką surenkamosios monolitinès perdangos su gelžbetonio liktiniais klojiniais kontakto zonos statiniam darbui.

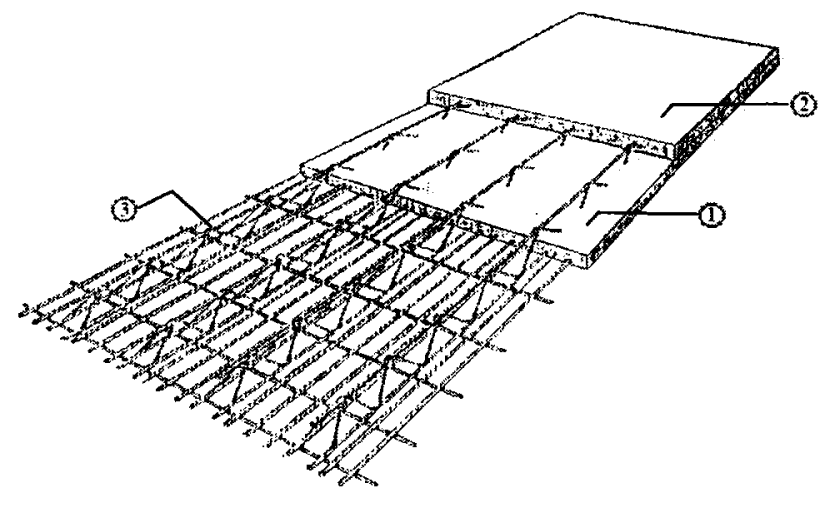

1 pav. Surenkamoji monolitinè perdanga su gelžbetonio liktiniais klojiniais: l - surenkamojo gelžbetonio liktinis klojinys, 2 - monolitinio gelžbetonio sluoksnis, 3 - jungiamasis strypynas

Fig 1. Reinforced precast concrete floor with survival moulds: 1 - precast reinforced concrete survival mould, 2 - reinforced concrete layer in situ, 3 - connecting vertical shear reinforcement

\section{Bendrieji principai ir skaičiavimo metodika}

Yra žinoma, kad lenkiamieji elementai yra veikiami momentụ, ašinių ir skersinių jègu, kurios sukelia tangentinius iłtempimus. Nagrinèjamu atveju pagrindinè problema yra tokie tangentiniai ittempimai, kurie atsiranda kontakto plokštumoje, o ju dydžiai pavojingose zonose gali būti artimi leistiniesiems. Juos būtina tinkamai ịvertinti ir nustatyti jų itaką ribinių būvių susidarymui.

Atliekant praktinius skaičiavimus laikoma, kad skersinès jẻgos gali sukelti greta esančių sluoksnių vertikaliuosius poslinkius - atsiranda tangentiniai įtempimai $\tau_{1}$. Tačiau sijos ir plokštès nuo apkrovos išlinksta, todèl sluoksniai pasislenka vienas kito atžvilgiu horizontalia kryptimi, atsiranda horizontalieji išilginiai tangentiniai itempimai $\tau_{\mathfrak{u}}$ ( 2 pav.). Jie yra didžiausi neutraliojoje ašyje arba kontakto plokštumoje. 


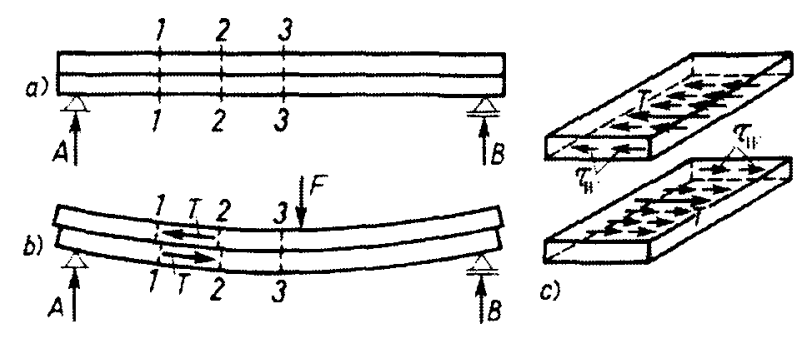

2 pav. Sluoksniuotas lenkiamasis elementas: a) neapkrauto lenkiamojo sluoksniuoto elemento schema; b) poslinkis ir išilginè šlyties jẻga nuo skersinès apkrovos vieno ant kito użdètų sluoksnių kontakto plokštumoje; c) horizontalieji išilginiai tangentiniai itempimai $\tau_{w}$ sluoksniu kontakto zonoje

Fig 2. Bending composite element: a) scheme of nonloaded bending composite element; b) lag and shear force in contact zone between layers; c) horizontal shear stresses $\tau_{w}$ in contact zone between layers

Remiantis literatūros šaltiniais [2-4], sudètinis (sluoksniuotas) lenkiamasis elementas iki atsirandant plyšiams gali būti skaičiuojamas analogiškai kaip ir gniuždoma arka, turinti tempiamą juostą. Didinant apkrovą atsiranda plyšiu, kurie suardo gniuždomos arkos struktūrą ir taip sumažina jos laikomają galią. Gelžbetonio elementas suirtu, jei nebūtụ armatūros, atlaikančios tangentinius itempimus. Kai tokia armatūra yra, galima sudaryti menamą skaičiuojamają santvarą ( 3 pav.), kurios viršutinè juosta sudaryta iš gniuždomojo betono, apatinè - iš tempiamosios armatūros. Elementụ ruožus tarp plyšiu galima isivaizduoti kaip ,gniuždomuosius betono spyrius" [5], o statmenai kertančią plyšius armatūra - kaip „tempiamuosius strypus“.

3 pav. pavaizduota santvara statiškai yra neišsprendžiama. Jos sprendimo būdas pavadintas Emilio Mörscho vardu [6]. Tačiau nemažai atliktụ eksperimentiniu tyrimu $[2,4]$ parodé, kad Emilio Mörscho klasikinio tipo santvaros modelis ( 3 a pav.) turi būti patikslintas, ivertinant tai, kad gniuždoma juosta yra ne horizontali, bet kiek išgaubta, o menamu gniuždomuju betono ,spyrių" posvyrio kampas mažesnis kaip $45^{\circ}$ ( $3 \mathrm{~b}$ pav.). Hipotetiškai galima laikyti, kad patikslinto santvaros modelio parametrus lemia horizontaliuju poslinkių (deformacijụ) kontakto plokštumoje (zonoje) poveikis. Šie poslinkiai turi būti ivertinti.

\section{Jégụ pasiskirstymas santvaros modeliuose}

Yra žinomas DIN 1045 [1] metodas, taikomas gniuždymo jègoms betono "spyriuose“" ivertinti pagal leistinuosius tangentinius itempimus ir EN [7], bei SNirT [8] metodikos skersinèms jègoms ivertinti. Žinant armatūros klasę, skerspjūvius ir elemento aukšti, nustatomas didžiausias atstumas tarp armatūros strypyno, siekiant, kad ịstrižas plyšys nedidètų per visą konstrukcijos aukštị ir nesusikirstụ su armatūra.

a)

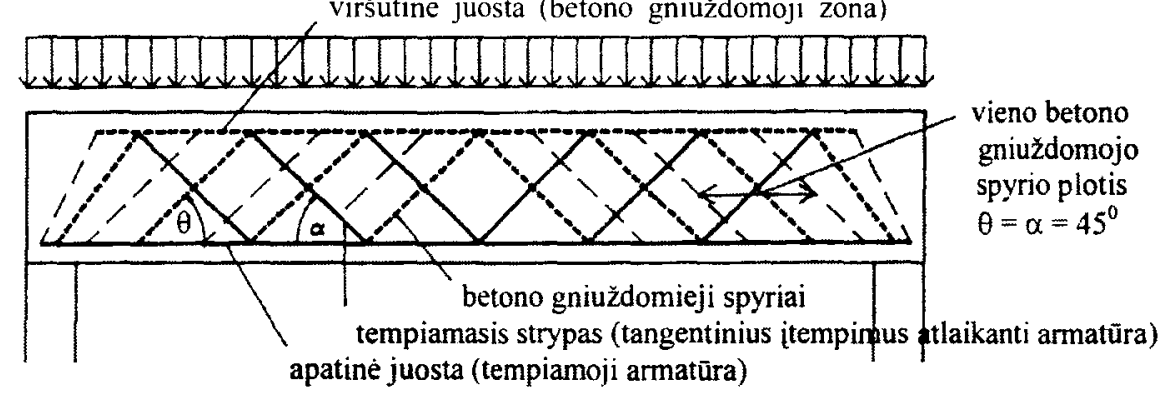

b)

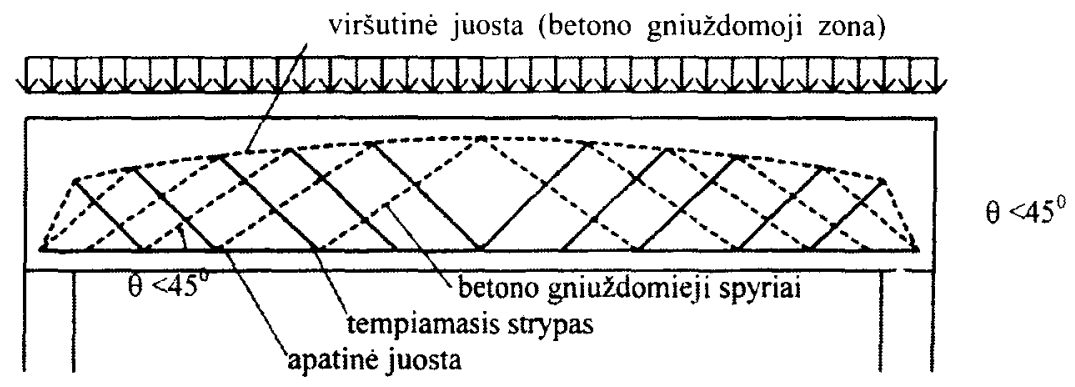

3 pav. Menamų skaičiuojamujų santvaru schemos: a) klasikinis modelis; b) patikslintas modelis

Fig 3. Schemes of imaginary design trusses: a) classical model; b) refined model 


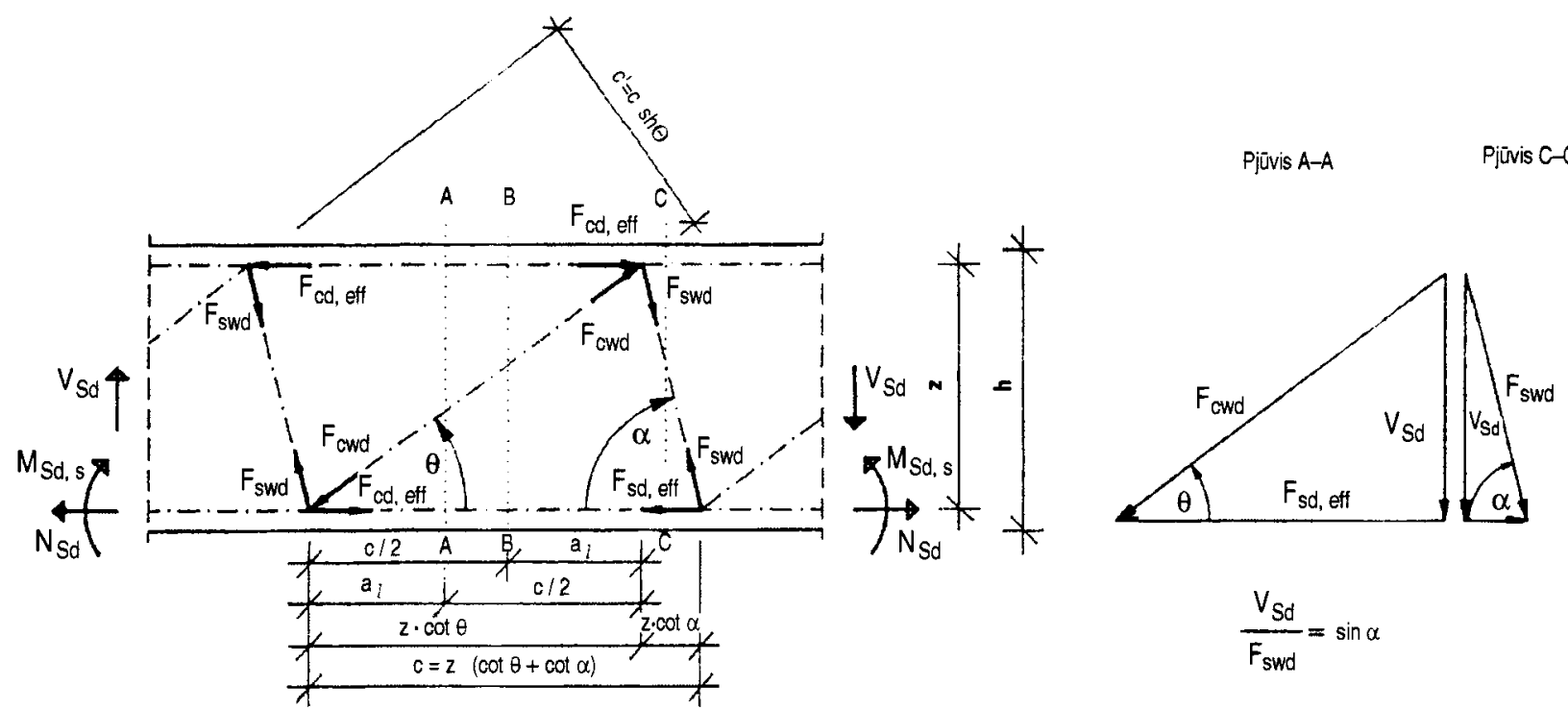

4 pav. Skaičiuojamujų jègų pasiskirstymas menamos santvaros modelyje (žymejjimai pagal EN2 [7])

Fig 4. Distribution of design forces in imaginary truss model (designationsin EN2 [7])

Skaičiuojamuju jègu pasiskirstymas menamos santvaros modelyje pagal EN2 [7] pavaizduotas 4 paveiksle.

Pagal klasikini modeli atstumas $c$ tarp strypyno sekcijų (žingsnis) įvertinamas formule:

$$
c=z(\operatorname{ctg} \theta+\operatorname{ctg} \alpha)
$$

$z$ - efektyvusis vidinių jègu petys esant tarnos būviui; $\theta$ - ,gniuždomujų“ spyriu posvyrio kampas; $\alpha$ - tempiamuju strypu posvyrio kampas.

Tangentiniai itempimai armatūros strypuose $\tau_{w d}$ bendruoju atveju $[9,10]$ nustatomi taip:

$$
\tau_{w d}=\frac{A_{s w} \cdot f_{i w d} \cdot \sin \alpha \cdot(\operatorname{ctg} \theta+\operatorname{ctg} \alpha)}{s_{S T} \cdot s_{w}}
$$

$A_{S w}$ - armatūros skerspjūvio plotas; $f_{y w d}$ - leistinieji armatūros îtempimai; $s_{S T}$ - armatūros strypynų žingsnis; $s_{w}$ - armatūros strypyno istrižujų strypụ žingsnis.

Čia laikomasi sąlygos, $\operatorname{kad} c=s_{\mathfrak{w}}$.

\section{4. Šlyties deformacijų ịtaka patikslintoje Ienkiamojo elemento schemoje}

Pagal $[2,5]$, didžiausi tangentiniai itempimai neutraliojoje plokštumoje skaičiuojami nuo skersinès jègos:

$$
\tau_{o d, \max }=\frac{V_{s d}}{b \cdot z},
$$

$V_{s d}$ - skersinè jèga; $b$ - elemento plotis; $z$ - vidinių jègu petys.

Veikiant šlyties jègoms, dali tangentinių itempimu perima gretutiniai sluoksniai, o veikiančių jègų dydžiai ir kryptys transformuojasi pagal schema, parodyta 5 pav. Ši transformacija turi būti ivertinta, skaičiuojant konstrukcijos laikomają galią.

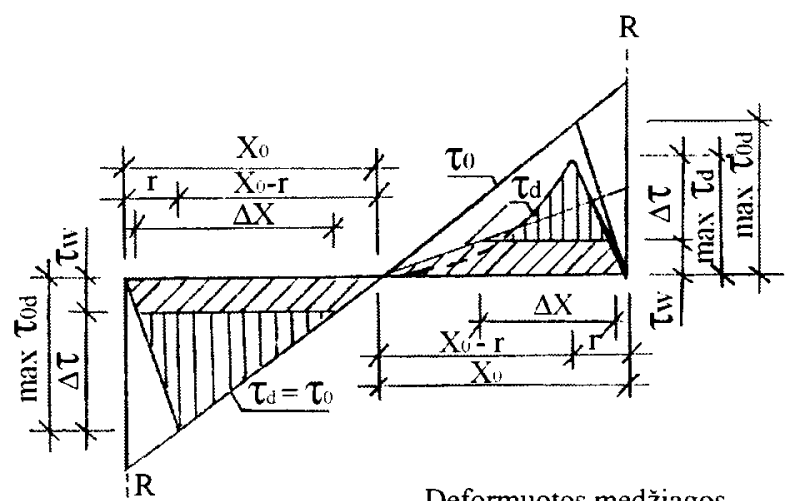

Visas tangentiniu ¡tempimų perémimas

Dériagos tangentiniu itempimu perémimas

5 pav. Tangentinių ittempimų transformacija veikiant šlyties jègoms

Fig 5. Transformations of shear stresses under shear forces

Remiantis prof. G. Marčiukaičio ir J. Valivonio [11] analitine medžiaga, nustatyta, kad esant pasislinkimui tarp sluoksniụ mažèja elemento standumas ir didejja konstrukcijos ilinkis. Tačiau pasislinkimas $\mathrm{x}$ ašies (horizontalia) kryptimi sumažeja dèl šlyties deformaciju $\psi_{x}$. Tuomet vertikaliujų (v) ir horizontaliujų (w) deformaciju atstojamoji $\psi(x)$ yra tokia: 


$$
\psi(x)=\frac{\partial w}{\partial y}+\frac{\partial v}{\partial x}
$$

ir tam tikra vidutinè šlyties deformacija pagal konstrukcijos aukštị bus:

$$
\psi(x)=\frac{1}{h} \int_{0}^{h} \gamma_{x y}(x, y) d y .
$$

Ten pat nurodoma, kad, žinant tangentiniu įtempimụ vertes, šlyties deformacijas tarp sluoksniu galima apskaičiuoti pagal tokią formulę:

$$
\psi_{x y}=\frac{1}{h} \int_{0}^{h} \frac{\tau_{x y} d x}{G_{x y}}
$$

$G_{x y}-$ šlyties modulis.

Remiantis pagal šią schemą atliktais teoriniais ir eksperimentiniais tyrimais daroma išvada, kad apkrovai didejant virš $0,5 M_{u}$ ribos, sluoksniuotụ lenkiamujų elementu deformatyvumas yra gerokai didesnis nei vienasluoksnių. Tačiau čia pat pastebima, kad sluoksniuotų konstrukciju deformatyvumas priklauso nuo sluoksniu ir kontakto tarp sluoksnių deformatyvumo.

Žinant, kad $\psi_{x y}=\varphi\left(\tau_{x y}\right)$, Ackermanas $[12,13]$ horizontaliąsias deformacijas išreiškia kaip trijụ i tempimu dèmenụ funkciją, išreikštą daugianariu:

$$
\psi=\varphi\left(\tau_{w}\right)=\varphi\left(\tau_{a d h}+\tau_{R w}+\tau_{B w}\right),
$$

čia paviršiụ adhezijos $\tau_{a d h}$, skersinès armatūros $\tau_{R w}$ ir betono $\tau_{B w}$ itempimai yra šios funkcijos demenys.

Šiuo daugianariu išskiriamas kontakto tarp liktinio klojinio (mūsu atveju) ir monolitinio sluoksnio (adhezijos) dèmuo. Suprantama, kad priklausomai nuo $\tau_{a d h}$ dydžio lenkiamujų sluoksniuotu elementu deformatyvumas turi mažèti ir savo verte artèti prie vienasluoksnès konstrukcijos deformaciju.

Atlikus specialiuosius tyrimus [12], nustatyta, kad horizontaliuju $(w)$ ir vertikaliuju (v) deformacijų atstojamoji (v) aprašoma rodikline funkcija:

$$
v=\alpha \cdot w^{2 / 3},
$$

$\alpha$ - proporcingumo daugiklis, priklausantis nuo kontakto zonos (plokštumos) šiurkštumo arba sankibumo.

Iš klasikinès mechanikos yra žinomos trinties tarp dviejų medžiagụ reikšmès ir jụ analitinè išraiška. Mūsụ atlikti paruošiamieji tyrimai, remiantis Sungatulino [14] atliktais eksperimentiniais duomenimis ir Ackermanno [12] „išraiška“", leidžia pateikti šias orientacines betono paviršių šiurkštumo reikšmes (1 lentelè):

1 lentelè. Betono paviršiaus šiurkštumo rodiklis $\alpha$

Table 1 . The index $\alpha$ of concrete surface roughness

\begin{tabular}{|l|c|}
\hline Paviršiaus šiurkštumo charakteristika & $\begin{array}{c}\text { Šiurkštumo } \\
\text { rodiklis } \alpha\end{array}$ \\
\hline Labai lygus paviršius & 0,12 \\
\hline Lygus paviršius & 0,2 \\
\hline Natūraliai šiurkštus paviršius & 0,3 \\
\hline Pašiurkštintas paviršius & 0,4 \\
\hline Stipriai pašiurkštintas paviršius & 0,5 \\
\hline
\end{tabular}

Imant lenkiamojo sluoksniuoto elemento šiurkštumo rodiklius $\alpha=(0,2 ; 0,3 ; 0,4$ ir 0,5$)$ pagal (8) išraiška nustatytas horizontaliuju (w) deformaciju dèmuo ( 2 lentelè):

2 lentelè. Lenkiamojo sluoksniuoto elemento horizontaliuju deformaciju dèmuo $w(\mathrm{~mm})$ skerspjūvio aukščio atžvilgiu

Table 2. Component $\mathrm{w}(\mathrm{mm})$ of horizontal strains in section of bending composite element

\begin{tabular}{|c|c|c|c|c|}
\hline \multirow{2}{*}{$\begin{array}{c}\text { Vertikaliosios } \\
\text { deformacijos } \\
\text { (ilinkis) v, mm }\end{array}$} & \multicolumn{4}{|c|}{ Paviršiaus šiurkštumo rodiklis $\alpha$} \\
\cline { 2 - 5 } & 0,2 & 0,3 & 0,4 & 0,5 \\
\hline 0,05 & 0,14 & 0,08 & 0,04 & 0,03 \\
\hline 0,10 & $>0,4$ & 0,2 & 0,14 & 0,09 \\
\hline 0,15 & - & $>0,4$ & 0,25 & 0,16 \\
\hline 0,20 & - & - & 0,28 & 0,27 \\
\hline 0,25 & - & - & $>0,4$ & 0,41 \\
\hline 0,30 & - & - & - & $>0,5$ \\
\hline
\end{tabular}

Pasinaudodami (2) ir (7) formulèmis atlikome analitini tyrimą - eksperimentą. Jo esmé yra ta, kad keisdami strypyno žingsnius, plokštès aukščius, armatūros klase, matematiniu nuosekliojo artejjimo metodu sudaréme palyginamaja patikslintų šlyties itempimų lentelę (3 lent.). Užtektino artėjimo kriterijus buvo gautụ rezultatụ koreliacija (glaustumas), atitinkanti (7) išraiškos kreivių trajektoriją. 
3 lentelè. Klasikiniu $\tau_{c l}$ ir patikslintu $\tau_{p t}$ metodu jvertintu skersiniu strypų perimamų tangentiniu ¿tempimu palyginimas. Čia $\mathrm{s}_{\mathrm{u}}=20 \mathrm{~cm}$. Betono klasé $-\mathrm{B} 15$

Table 3. Comparable evaluation of successive shear stresses $\tau_{c l}$ and $\tau_{p t}$ in stirrups. $s_{n}=20 \mathrm{~cm}$, concrete class B 15

\begin{tabular}{|c|c|c|c|c|c|c|}
\hline \multirow{2}{*}{\begin{tabular}{c}
\multirow{2}{*}{$S_{s \tau}$} \\
{$[\mathrm{cm}]$}
\end{tabular}} & \multicolumn{3}{|c|}{$\tau_{p t}\left[\mathrm{MN} / \mathrm{m}^{2}\right]$} & \multicolumn{3}{c|}{$\tau_{c l}\left[\mathrm{MN} / \mathrm{m}^{2}\right]$} \\
\cline { 2 - 7 } & 5 & 6 & 7 & 5 & 6 & 7 \\
\hline 25 & 0,264 & 0,384 & 0,522 & 0,264 & 0,384 & 0,522 \\
\hline 35 & 0,188 & 0,274 & 0,373 & 0,215 & 0,274 & 0,373 \\
\hline 40 & 0,165 & 0,240 & 0,327 & 0,201 & 0,242 & 0,327 \\
\hline 50 & 0,132 & 0,192 & 0,261 & 0,180 & 0,217 & 0,261 \\
\hline 60 & 0,110 & 0,160 & 0,218 & 0,164 & 0,198 & 0,231 \\
\hline 70 & 0,094 & 0,137 & 0,187 & 0,152 & 0,183 & 0,214 \\
\hline
\end{tabular}

Pastaba. Apibrauktos $\tau_{c l}$ vertès yra didesnès už $\tau_{p t}$ vertes.
Iš 3 lentelès matyti, kad, didèjant sST, skirtumas $\operatorname{tarp} \tau_{c l}$ ir $\tau_{p t}$ verčių dideja. Šis skirtumas dar labiau didèja, didèjant betono klasei, o jungiančiosios armatūros laikomoji galia geriau išnaudojama iki leistinuju itempimu.

\section{Taikomieji denginių, sudarytų iš liktinių klojinių ir monolitinẻs gelžbetoninès plokštès, rezultatai}

Remiantis gautomis armatūros strypyno ịstrižujų strypu, atlaikančių tangentinius ịtempimus, modifikuotomis skaičiavimo lygtimis, atlikta tangentinių itempimų pasiskirstymo grafinè analizè. Buvo nagrinèta 10 variantų, keičiant atstumą tarp armatūros strypynų, atitinkamai, $25 ; 30 ; 37,5 ; 44 ; 48 ; 50 ; 55 ; 60 ; 62,5$ ir $75 \mathrm{~cm}$. Taip pat išanalizuota, kokią ittaką daro armatūros skersmens $(\varnothing 5 ; \varnothing 6 ; \varnothing 7 ; \varnothing 8)$ keitimas armatūros strypyno aukščiui. Imant, kad istrižujų strypu žingsnis $\mathrm{sw}=\mathrm{const}$, atitinkamai buvo ivertintas strypyno posvyrio kampo $\alpha$ kitimas.

6 paveiksle pateikiamas suvestinès tangentiniụ itempimų funkcinès priklausomybès nuo atstumo tarp armatūros strypynu pavyzdys, keičiant armatūros skersmenị.

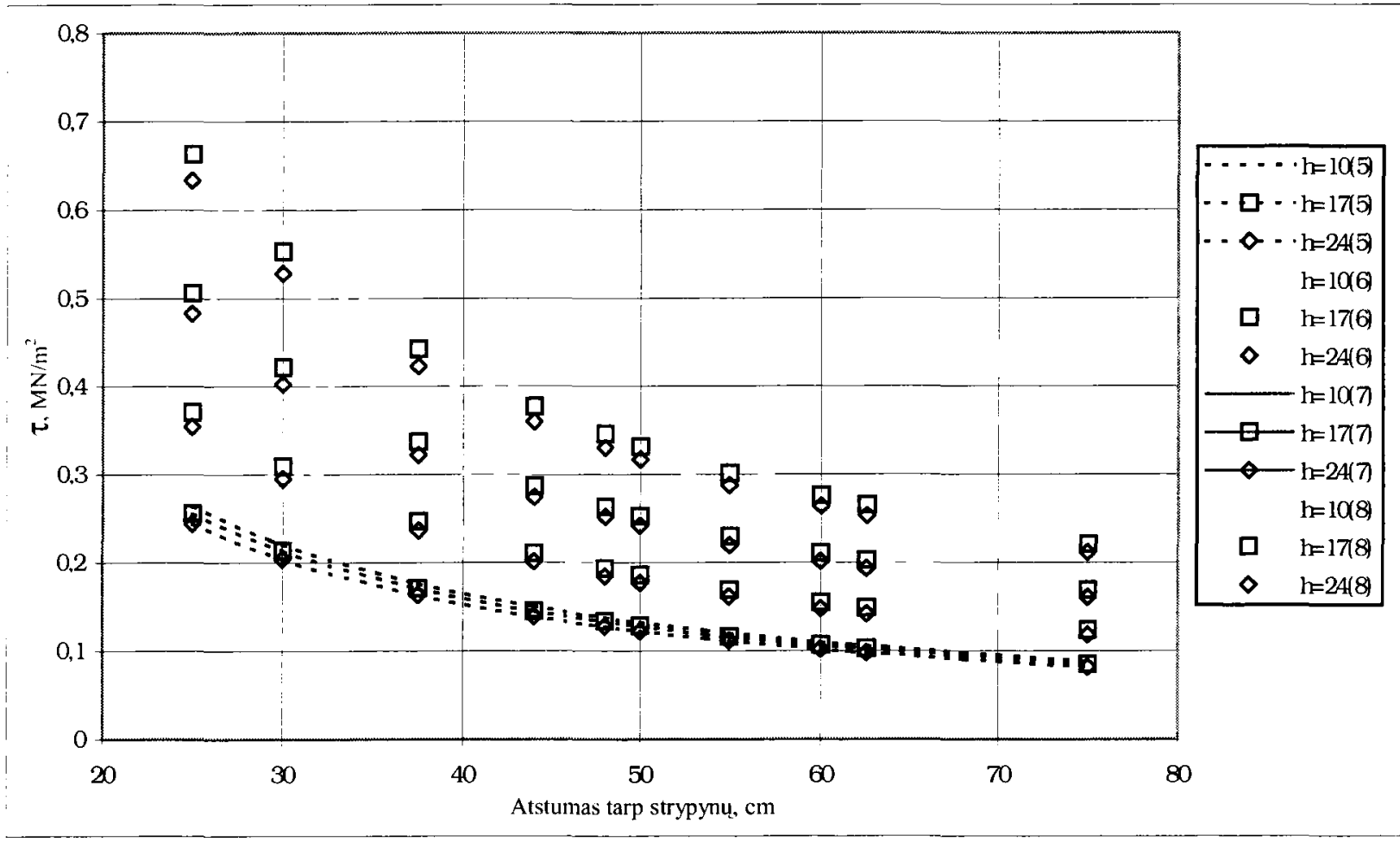

6 pav. Tangentinių ṫempimu priklausomybè nuo atstumo tarp strypynų

Fig 6. Dependency of shear stresses on the distance of vertical shear reinforcement 


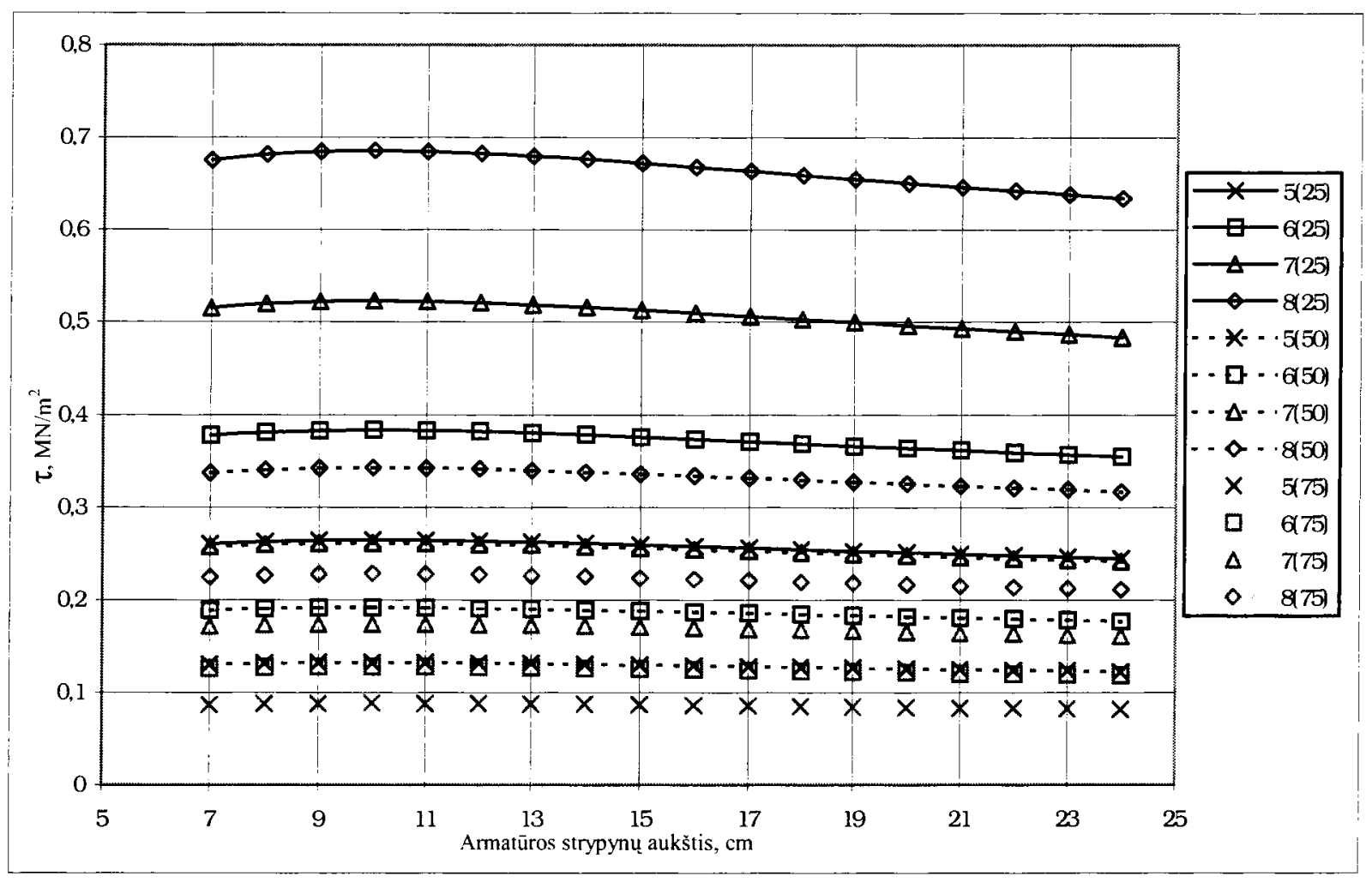

7 pav. Tangentiniu itempimų priklausomybẻ nuo armatūros strypyno aukščio

Fig 7. Dependency of shear stresses on the height of vertical shear reinforcement

Suvestinio 6 paveikslo duomenys rodo, kad strypyno žingsniui didèjant virš $60 \mathrm{~cm}$, šlyties itempimụ skirtumas, keičiant armatūros skersmeni ir elemento aukštị, artèja prie pastoviojo dydžio: $c \rightarrow$ cont. Taip pat mažèja absoliuti ịtempimų skirtumų vertè - nuo $\Delta \tau_{25}=0,45$ $\mathrm{MN} / \mathrm{m}^{2}$ iki $\Delta \tau_{75}=0,13 \mathrm{MN} / \mathrm{m}^{2}$.

Iš 7 pav. suvestinių duomenụ matyti, kad strypyno aukščio kitimo itaka yra pastovusis dydis, jeigu reguliuojamas strypyno skersmuo ir žingsnis. Taigi racionalus konstrukcijos armavimo sprendimas priklauso nuo armatūros sąnaudu palyginimo, laikantis minimalaus ir maksimalaus armavimo reikalavimu. Naudingiau naudoti didesnio skersmens armatūrą.

\section{Išvados}

1. Lenkiamos dvisluoksnès gelžbetonio plokštès gali būti skaičiuojamos pagal menamos, kiek išgaubtos santvaros modelị, ivvertinant ir itraukiant i plokštes statini darbą vertikalų strypyną.

2. Skaičiuojamoji schema leidžia ivertinti šlyties itempimus kontakto zonoje (plokštumoje), remiantis šlyties itempimu transformacija plokštei ilinkus.
3. Ivertinus kontakto zonos (plokštumos) paviršiu šiurkštumą, galima maksimaliai išnaudoti jungiamojo strypyno laikomają galią ir sumažinti plokštẻs deformacijas (ilinki) iki lygio, artimo vienasluoksnei konstrukcijai.

\section{Literatūra}

1. DIN 1045. Beton und Stahlbeton, Ausgabe Juli, 1988. $96 \mathrm{~S}$.

2. R. Avak. Stahlbetonbau in Beispielen: DIN 1045 und europäische Normung / Ralf Avak. Düsseldorf: Werner. Teil 1. Baustoffe, Grundlagen, Bemessung von Stabtragwerken. 2, neubearb. u. erw. Aufl. 1994. 354 S.

3. Chu-Kia Wang, Charles G. Salmon. Reinforced Concrete design. Sixth Edition. Menlo Park, California Reading, Massachusetts New York Harlov, England Barkeley, California Don Hills, Ontario Sydney Bonn Amsterdam Tokyo Mexico City, 1995. $1020 \mathrm{~S}$.

4. Ф. Леонгард. Предварительно напряженный железобетон. Москва: Стройиздат, 1983. 245 с.

5. G. Lohmeyer, Gottfried C.O. Stahlbetonbau: Bemessung, Konstruktion, Ausführung / von Gottfried C.O. Lohmeyer. 3, neubearb. u. erw. Aufl. Stuttgart: Teubner, 1983. $434 \mathrm{~S}$. 
6. H. Bay. Emil Mörsch. Erinnerungen an einen großen Lehrmeister des Stahlbetonbaus und techn. Mentor der Wayss \& Freytag AG; Düsseldorf, VDI-Ges. Bautechnik, 1985 (Herausragende Ingenieurleistungen in der Bautechnik, Heft 3). $20 \mathrm{~S}$.

7. DIN V ENV 1992-1-1. Eurocode 2, Planung von Stahlbeton und Spannbetontragwerken, Ausgabe Juni, 1992. $312 \mathrm{~S}$.

8. СНиП 2.03.01-84. Бетонные и железобетонные конструкции. Москва, 1989. 88 с.

9. Institut für Bautechnik, Berlin: Zulassungsbescheid $\mathrm{Nr}$. Z-4.1-89 für den Kaiser - Gittertäger KT800, Blatt 8.5.3.

10. Institut für Bautechnik, Berlin: Schreiben 1 13-1089 vom 09, Juni 1992 an Badische Drahtwerke GmbH, Kehl.

11. G. Marčiukaitis, J. Valivonis. Ryšių standumo tarp sluoksnių itakos lenkiamų sluoksniuotujų armuotų sijų jlinkiams vertinimas // Statybinès konstrukcijos: kūrimas ir stiprinimas: Konferencijos. ivykusios Vilniuje $1998 \mathrm{~m}$. lapkričio 20 d., medžiaga. Vilnius: Technika, 1998, p. 38-42.

12. G. Ackermann, R. Gatzsch. Schubversuche zur Bestimmung charakteristischer Kennwertfunktionen an bewehrten Verbundfugen bei Fertigteilen und Ortbeton // Wiss. Z. Hochsch. Archit. Bauwes. A/B. Weimar 39 (1993) 3, S. 191-203.

13. G. Ackermann, R. Gatzsch. Versuchsergebnisse zum Tragverhalten von bewehrten Verbundfugen bei Fertigteilen und Ortbeton // Beton- und Stahlbetonbau 89(1994), H. 5, S. $145-148$.

14. Я. Г. Сунгатуллин. Экспериментально-теоретические основы расчета сопротивляемости сдвигу армированного и неармированного контактов сборно-монолитных конструкций // Сборные и сборно-монолитные железобетонные конструкции. Межвузовский сборник трудов, № 1. Казань - Ленинград, 1975, с. 90-145.

Iteikta 20000718

\section{EVALUATION OF SURFACE ROUGHNESS AND VERTICAL SHEAR REINFORCEMENT IN CONTACT ZONE OF REINFORCED CONCRETE CONSTRUCTIONS WITH SURVIVAL MOULDS}

\section{R. Bistrickaitė}

\section{Summary}

Structurally and technologically expedient and economic precast-monolithic reinforcement floor slabs are widely used in western European countries. In Lithuania they are unknown, although there are all conditions for introducing them.

Precast-monolithic slabs are made from precast layers (used as survival moulds) and monolithic layers (poured in situ). These layers are connected to make a compact structure with vertical shear reinforcement.

There exists a method for calculating slabs analogous to a curved top truss. According to this method, the deflection of composite slabs increases considerably compared with that of one-layer structures.

By evaluating both the transformation of tangential shear stress in the cross-section of bending elements and the influence of adhesive power in the contact zone, we have defined in a more exact way the method for calculating composite slabs. Additionally, we have included a vertical reinforcement into the structure and diminished vertical deflections of slabs up to the values close to those of one-layer structures.

Rèda BISTRICKAITÉ. PhD student. Dept of Building Structures. Kaunas University of Technology (KTU), Studenty g. 48, LT-3031 Kaunas, Lithuania.

E-mail: romualdas.zilinskas@saf.ktu.lt

A graduate of KTU (1995). Doctoral studies at KTU (1995-2000). Author of 4 publications. Research interests: reinforced concrete structures, peculiarities of layered structures. 